\title{
Multi-factorial Etiology of Bipolar Disorder and Schizophrenia in Iran: No Evidence of Borna Disease Virus Genome
}

Ameneh Arab (MSc)

Research Committee, Faculty of Medicine, Golestan University of Medical Sciences, Gorgan, Iran Alireza Mohebbi (MSc) Behavioral Sciences Research Center, Isfahan University of Medical Sciences, Isfahan, Iran

Hamid Afshar (MSc)

Behavioral Sciences Research Center, Isfahan University of Medical

Sciences, Isfahan, Iran

Abdolvahab Moradi (PhD)

Infectious Diseases Research Center,

Golestan University of Medical

Sciences, Gorgan, Iran

Corresponding author: Abdolvahab Moradi

E-mail: abmoradi@gmail.com

Tel: +9817 32421653

Address: Infectious Diseases Research Centre, Golestan University of Medical Sciences, Gorgan, Iran

Received : 07 Jun 2017

Revised: 02 Jun 2018

Accepted: 18 Jun 2018

\section{ABSTRACT}

Background and 0bjectives: Psychiatric disorders such as schizophrenia and bipolar disorder pose a high burden among the general population. Etiological factor(s) of such disorders remain unknown. Borna disease virus (BDV) is a neurotropic virus that has been suggested as an etiological agent for psychiatric disorders. Therefore, we aimed to investigate the prevalence of BDV among patients with schizophrenia and bipolar disorder.

Methods: Peripheral blood mononuclear cells (PBMCs) of schizophrenic $(\mathrm{n}=75)$ and bipolar $(n=55)$ patients and healthy blood donors $(n=125)$ were extracted form whole blood samples. RNA was extracted from PBMCs and the presence of BDV P40 RNA was assessed by reverse transcription-polymerase chain reaction.

Results: The BDV genome was not detected in any of the subjects. Positive family history of disease was significantly more frequent among patients $(\mathrm{P}=0.0001)$. There was a significant association between contact with animals and psychiatric illnesses $(\mathrm{P}<0.05)$. Moreover, education level differed significantly between the two groups $(\mathrm{P}<0.05)$.

Conclusion: The results indicate no evidence of BDV genome among patients with psychiatric disorders. Serological examination for BDV antigens or antibodies could provide further information in this regard. In addition, contact with cats is significantly more prevalent among patients with mental illnesses, which might be due to infection with Toxoplasma gondii.

Keywords: Borna disease virus, Psychiatric disorder, Schizophrenia, Bipolar disorder, Risk factors. 


\section{INTRODUCTION}

Schizophrenia and bipolar disorder are disabling mental illnesses with complex etiologies. Both genetic and environmental factors affect the development of these illnesses (1). These factors include genetics (2), family history of the disease (3), season and place of birth (4), and infectious agents (5).

Family studies have demonstrated that affected patients with familial history of psychosis have a higher risk of developing the disorders. In addition, various environmental factors have been evaluated as risk factors for psychosis (6). Among infectious agents considered as risk factors for the diseases, Toxoplasma gondii has been observed in patients with schizophrenia (7) and bipolar disorder (8). Additionally, there are several studies indicating the role of viral infections and human psychoses (9). Presence of Borna disease virus (BDV) infections have been investigated among various human populations with mental illnesses (10-14).

BDV is an enveloped, single-stranded, nonsegmented RNA virus from the Bornaviridae family. The virus is highly neurotropic, noncytolytic, and a pathogen of the central nervous system (CNS) in various vertebrate species (15). It has been suggested that the virus may be transmitted through the nose, saliva, and conjunctival secretions (16). BDV might reach the CNS through axonal migration via the oropharyngeal olfactory nerve, where it reaches the peripheral nerves (17). Depending on age, immunity status, and the host species, the virus can cause CNS disorders with diverse manifestations (18). For example, BDV infection can result in severe immune responses in brain cells of rats with motion abnormality, or induce persistent infection and cognitive disorders in newborn rats $(19,20)$.

Similar to animal models, infection of humans with BDV initially affects the brain, which is followed by psychiatric and neurological symptoms (21). Transmission of the virus to humans through infected animals is also possible (17). Behavioral health studies on animals infected with BDV have led to the idea that BDV infection in humans may be associated with psychiatric illnesses, such as mood and psychotic disorders (22). Epidemiological studies using peripheralblood mononuclear cells (PBMCs) and brain tissues have shown that BDV can infect humans and may be associated with certain neuropsychiatric disorders (12).

In schizophrenia, the presence of antibodies against BDV antigens has been identified. Waltrip et al. found anti-BDV antibodies in $14.4 \%$ of schizophrenic patients (23). There may be a possible relationship between BDV and certain affective disorders such as unipolar and bipolar disorders, and major depression (19). Amsterdam and colleagues detected BDV antibodies in $4.5 \%$ of patients with affective disorders (24). Bode et al. found BDV antibodies in $20 \%$ of admitted patients with major depression (25).

In several studies, BDV genome (P24, P40) has been identified in brain tissue, cerebrospinal fluid (CSF) samples, and PBMCs using various polymerase chain reaction (PCR) methods including, reverse transcriptase-PCR (RT-PCR), nested PCR, quantitative fluorescent-PCR, and real timePCR $(26,27)$. Xu et al. detected BDV P24 sequence in $9.7 \%$ of patients with schizophrenia using RT-PCR (28). Borna virus infection is reported to be more frequent in young populations (17-30 years old) suffering from mental disorders (29).

Given the importance of mental disorders and their impact on quality of life of patients and their families, it is crucial to conduct extensive research on the cause(s) of mental disorders and subsequent prevention and treatment methods. In the present study, presence of the BDV P40 gene was evaluated among patients with psychiatric disorders and healthy blood donors using RT-PCR. Furthermore, we explored factors that have been suggested to be associated with mental illnesses in our cohort, including family history of the disease, education level, etc.

\section{MATERIAL AND METHODS}

Blood samples from 125 DSM-IV diagnosed psychiatric patients (75 patients with schizophrenia and 55 with bipolar disorder) and 125 age- and sex-matched healthy blood donors (57 female and 68 male) with no history of drug abuse and mental illnesses were collected from several mental health facilities in Isfahan, Iran. The patients were under antipsychotic treatment. The subjects were selected through randomized sampling and diagnosis was confirmed based on psychological tests by a physician. 
Information such as age, sex, education level, occupation, family history of mental illness, and contact with animals were obtained. Depending on the subjects' physical and mental health status, data were collected via a questionnaire with the help of the patients or healthcare staff, and from patients' medical records. Exclusion criteria included having psychiatric disorders other than bipolar and schizophrenia, positive result for chronic viral diseases such as hepatitis B, C or HIV, not participating in sample collection, and incomplete filling of the questionnaire. The study received approval from the ethics committee of the Golestan University of Medical Sciences (approval code: 25181693102115). Informed consent was obtained from the patients or their families.

Whole blood samples were used to separate PBMCs. RNA extraction was done using RNX-Plus kit (Cat no. RN7713C; Cinnagen, Iran) according to the manufacture ${ }^{\mathrm{r}}$ 's instructions. Purity of the extracted RNA was assessed using a spectrophotometer (Eppendorf, Germany) by reading optical densities at 260/280 $\mathrm{nm}$ and 260/230 $\mathrm{nm}$. One $\mu \mathrm{g}$ of the extracted RNA was used as template for cDNA synthesis using the RevertAid First Strand cDNA Synthesis Kit, according to manufacturer's instructions (Cat no. K1622; Thermo Fisher Scientific, Germany). GAPDH with the following primers was used as the control for cDNA synthesis: (Forward) 5'GAAGGGGAAGGTCGGAGT-3', (Reverse):

\section{5'-GAAGATGGTGATGGGATTTC-3'.}

Presence of the BDV genome (p40 coding region) in the samples was analyzed by conventional PCR based on the manufacturer's instructions (Cat no. 100103; Ampliqon, China), and using the following primers encompassing nucleotides 259 to 829 within the BDV genome: (Forward) 5'TTCATACAGTAACGCCCAGC-3’and (Reverse) 5 GCAACTACAGGGATTGTAAGGG-3'. The amplification reaction conditions were as follows: $95{ }^{\circ} \mathrm{C}$ for $5 \mathrm{~min}$, followed by 35 cycles of $95{ }^{\circ} \mathrm{C}$ for 45 seconds, $58{ }^{\circ} \mathrm{C}$ for 45 second, and $72{ }^{\circ} \mathrm{C}$ for $1 \mathrm{~min}$. A plasmid containing the BDV p40 gene (provided by Dr. Majid Bouzari, Isfahan University) was used as positive control.

Data analysis was performed with SPSS 16.0 using descriptive statistics and Chi-square test at $95 \%$ confidence interval (CI). P-values less than 0.05 were considered as significant.

\section{RESULTS}

Among total of 250 participants, 114 were female and 136 were male with a mean age of $36.82 \pm 10.854$ and $37.90 \pm 13.632$ years, respectively. As shown in table $1,62.26 \%$ of bipolar patients were female, while $65.71 \%$ of schizophrenic patients were male. There was no significant difference between the schizophrenic and bipolar patients in terms of sex. BDV RNA was not found in any of the samples.

Table 1-Distribution of schizophrenic and bipolar patients based on sex and age

\begin{tabular}{lll}
\hline Groups & Number $(\%)$ & Age (mean \pm standard deviation) \\
\hline Healthy blood donors & $\mathbf{1 2 5}(\mathbf{5 0 \%})$ & $\mathbf{3 8} \pm \mathbf{1 3 . 7 6 5}$ \\
Male & $\mathbf{6 8}(\mathbf{2 7 . 2 \%})$ & $\mathbf{3 8 . 3 8} \pm \mathbf{1 5 . 4 1 9}$ \\
Female & $\mathbf{5 7}(\mathbf{2 2 . 8 \%})$ & $\mathbf{3 7 . 5 4} \pm \mathbf{1 1 . 6 0 8}$ \\
Schizophrenic & $\mathbf{7 0}(\mathbf{2 8 \%})$ & $\mathbf{3 6 . 4 7} \pm \mathbf{1 0 . 6 1 4}$ \\
Male & $\mathbf{4 6}(\mathbf{1 8 . 4 \%})$ & $\mathbf{3 7 . 0 7} \pm \mathbf{1 1 . 7 6 5}$ \\
Female & $\mathbf{2 4}(\mathbf{9 . 6 \%})$ & $\mathbf{3 5 . 3 3} \pm \mathbf{8 . 0 6 9}$ \\
Bipolar & $\mathbf{5 3}(\mathbf{2 1 . 2 \%})$ & $\mathbf{3 7 . 6 6} \pm \mathbf{1 1 . 4 3 2}$ \\
Male & $\mathbf{2 0}(\mathbf{8 \%})$ & $\mathbf{3 9 . 3 0} \pm \mathbf{1 1 . 5 2 6}$ \\
Female & $\mathbf{3 3}(\mathbf{1 3 . 2 \%})$ & $\mathbf{3 6 . 6 7} \pm \mathbf{1 1 . 4 3 6}$ \\
Both diseases & $\mathbf{2}(\mathbf{0 . 8 \%})$ & $\mathbf{2 6 . 5 0} \pm \mathbf{7 . 7 7 8}$ \\
Male & $\mathbf{2}(\mathbf{0 . 8 \%} \%$ & $\mathbf{2 6 . 5 0} \pm \mathbf{7 . 7 7 8}$ \\
Female & $\mathbf{0}(\mathbf{0 \%})$ & - \\
\hline
\end{tabular}

Of 250 patients and healthy blood donors, only $73(29.2 \%)$ had a positive family history of psychiatric disorders. Among patients with psychiatric disorders, 51.2\% (64/125) had a family history of psychiatric disorders. More specifically, $30(56.6 \%)$ patients with bipolar disorder, 33 (47.1\%) patients with schizophrenia, and one $(50 \%)$ patient with both illnesses had a family history of mental disorders.

Positive family history of mental illness was significantly more prevalent among patients compared with the controls (Pearson's Chisquare, 64:9, $\left.\mathrm{X}^{2}(1)=58.529, p=0.0001\right)$. Table 2 shows the demographic information of patients and healthy controls. 
Results indicated a significant association between contact with pets or farm animals and psychiatric diseases.

The number of patients $(21,16.8 \%)$ with history of contact with cats was significantly higher than the controls $(3,0.24 \%)$ (Pearson's, $\left.\mathrm{X}^{2}(1)=14.934, \mathrm{P}<0.001\right)$. The ratio of patients to controls in terms of contact with animals was 11:5. Positive history of contact with horses was found to be more common in patients than in the controls (Pearson's, $\mathrm{P}=$ 0.098).

There was no significant difference in terms of contact with other animals including rabbit, sheep, fowl, cattle, dog, donkey, camel, and hamster between schizophrenic and bipolar patients. The subjects were divided into three categories based on their education level: high
(Bachelor's degree, Master's degree and $\mathrm{PhD}$ ), moderate (Diploma and Associated degree) and low (Illiterate, Elementary, Middle school, and High school). Based on the results, 30.8\% of all participants (77/250) were in the low education group, $37.6 \%(94 / 250)$ were in the moderate education group, and $31.6 \%$ were in the high education group. As illustrated in figure 1, the level of education was significantly higher in the control subjects compared with the patients (Pearson's Chisquare, $\left.X^{2}(2)=33.779, \quad P<0.0001\right)$. In addition, female patients had a significantly higher education level compared with male patients (Pearson's Chi-square, $\mathrm{P}<0.05$ ). There was no significant difference between the schizophrenic and bipolar patients in terms of education level.

Table 2- Demographics of patients and healthv blood donors

\begin{tabular}{|c|c|c|c|c|c|c|c|c|c|c|c|c|c|c|c|c|c|}
\hline \multirow[t]{2}{*}{ Groups } & \multicolumn{2}{|c|}{ Place of residence } & \multicolumn{3}{|c|}{ Traveling history } & \multicolumn{12}{|c|}{ Household size } \\
\hline & Countryside & $\begin{array}{l}\text { Isfaha } \\
\text { n city }\end{array}$ & $\begin{array}{c}\text { Non } \\
\text { e }\end{array}$ & $\begin{array}{c}\text { Domesti } \\
\text { c }\end{array}$ & $\begin{array}{c}\text { Abroad } \\
\& \\
\text { Domesti } \\
\text { c }\end{array}$ & 1 & 2 & 3 & 4 & 5 & 6 & 7 & 8 & 9 & $\begin{array}{l}\mathbf{1} \\
\mathbf{0}\end{array}$ & $\begin{array}{l}1 \\
1\end{array}$ & $\begin{array}{l}1 \\
2\end{array}$ \\
\hline $\begin{array}{l}\text { Healthy } \\
\text { Controls }\end{array}$ & & & & & & & & & & & & & & & & & \\
\hline Male & 30 & 38 & 2 & 44 & 22 & $\mathbf{0}$ & $\begin{array}{l}1 \\
5\end{array}$ & $\begin{array}{l}2 \\
0\end{array}$ & $\begin{array}{l}2 \\
7\end{array}$ & 5 & 1 & $\mathbf{0}$ & $\mathbf{0}$ & $\mathbf{0}$ & $\mathbf{0}$ & $\mathbf{0}$ & $\mathbf{0}$ \\
\hline Female & 15 & 42 & $\mathbf{0}$ & 40 & 17 & 1 & 6 & $\begin{array}{l}2 \\
1\end{array}$ & $\begin{array}{l}2 \\
1\end{array}$ & 6 & 2 & $\mathbf{0}$ & $\mathbf{0}$ & $\mathbf{0}$ & $\mathbf{0}$ & $\mathbf{0}$ & $\mathbf{0}$ \\
\hline $\begin{array}{l}\text { Schizophr } \\
\text { nic }\end{array}$ & & & & & & & & & & & & & & & & & \\
\hline Male & 16 & 30 & 14 & 31 & 1 & 5 & 6 & $\begin{array}{l}1 \\
\mathbf{0}\end{array}$ & $\begin{array}{l}1 \\
\mathbf{0}\end{array}$ & 9 & 2 & 1 & 2 & $\mathbf{0}$ & $\mathbf{0}$ & $\mathbf{0}$ & 1 \\
\hline $\begin{array}{l}\text { Female } \\
\text { Bipolar }\end{array}$ & 7 & 17 & 4 & 14 & 6 & 1 & 3 & 3 & 7 & 5 & 3 & $\mathbf{0}$ & $\mathbf{0}$ & 1 & 1 & $\mathbf{0}$ & $\mathbf{0}$ \\
\hline Male & 4 & 16 & 5 & 15 & $\mathbf{0}$ & $\mathbf{0}$ & 5 & 4 & 3 & 4 & 1 & 3 & $\mathbf{0}$ & $\mathbf{0}$ & $\mathbf{0}$ & $\mathbf{0}$ & $\mathbf{0}$ \\
\hline Female & 14 & 19 & 5 & 25 & 3 & 1 & 3 & 8 & $\begin{array}{l}1 \\
3\end{array}$ & 7 & 1 & 0 & 0 & 0 & 0 & 0 & 0 \\
\hline $\begin{array}{l}\text { Both } \\
\text { Male }\end{array}$ & 0 & 2 & 1 & 1 & 0 & 0 & 0 & 0 & 2 & 0 & 0 & 0 & 0 & 0 & 0 & 0 & 0 \\
\hline Total & 88 & 164 & 31 & 170 & 49 & 8 & $\begin{array}{l}3 \\
8 \\
\end{array}$ & $\begin{array}{l}6 \\
6 \\
\end{array}$ & $\begin{array}{l}8 \\
3 \\
\end{array}$ & $\begin{array}{l}3 \\
6 \\
\end{array}$ & $\begin{array}{l}1 \\
\mathbf{0}\end{array}$ & 4 & 2 & 1 & 1 & 0 & 1 \\
\hline
\end{tabular}

Figure 1 -Education level of patients and healthy controls

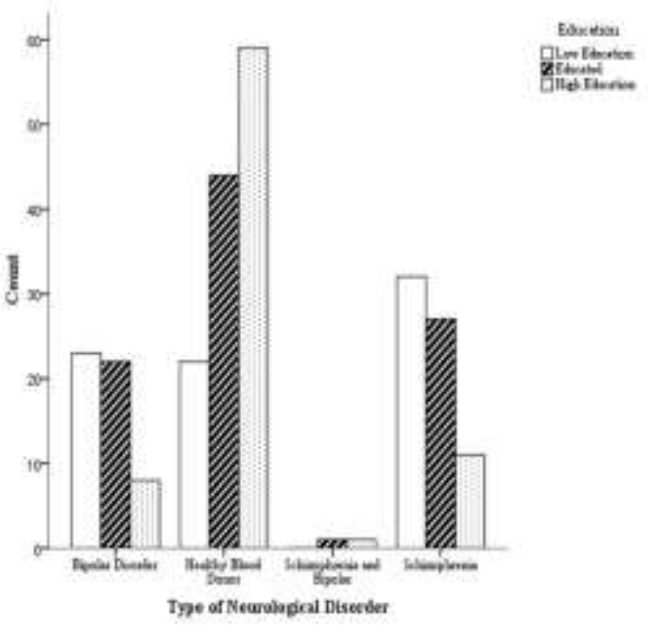




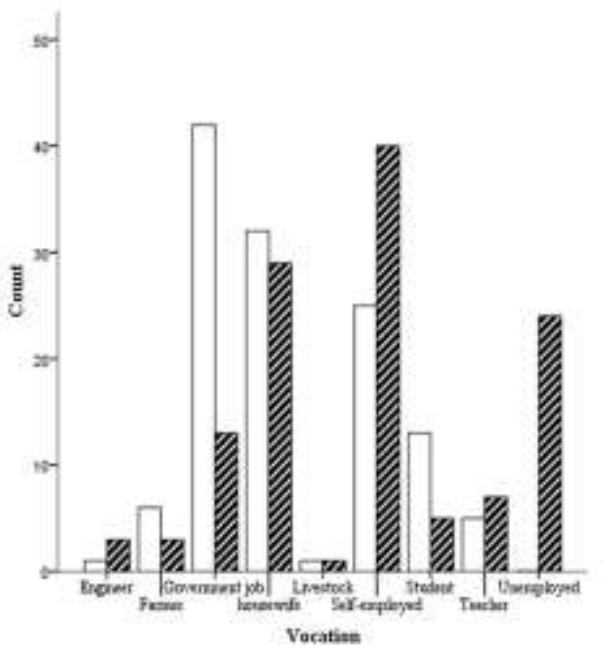

\section{DISCUSSION}

The epidemiology and clinical complications of human BDV infection remain controversial. Although most reports of the association between infection and mental disorders have focused on unipolar depression, bipolar disorder and schizophrenia (30), BDV has also been implicated in a wide range of disorders including, chronic fatigue syndrome and multiple sclerosis $(31,32)$. The vast majority of these studies have been based on molecular or serological methods. Limited number of studies have attempted to isolate an infectious virus from humans with psychiatric illnesses $(15,18)$. Most investigations have used nested RT-PCR, a method prone to amplification artifacts due to inadvertent introduction of template from laboratory isolates or cross-contamination of samples (33). Methods used for serological diagnosis of infections include indirect immunofluorescence of infected cells, immunoblotting, enzyme-linked immunosorbent assay of infected cell extracts or recombinant proteins, and circulating immune complex (CIC) assay $(11,13,26)$.

In contrast with our findings, several studies have found RNA of the BDV virus in patients with psychiatric disorders $(34,35)$. However, considering reports of presence of the virus in healthy blood donors, the etiological role of the virus remains controversial (36). Some studies reported no sign of BDV genome and specific antibodies in patients with cognitive disorders (37-39). In addition to RT-PCR, the CIC method can be used for investigating the presence of virus because of its ability to uncover circulating anti-BDV immune complexes in a host $(10,40,41)$. Different methods such as nested RT-PCR and CIC have been applied in studies performed in Iran $(10,14,27)$. Based on these studies, prevalence of BDV RNA among psychiatric patients and blood donors was $6 \%$ and $2.2 \%$, respectively. Mazaheri et al. showed the presence of CICs of BDV in more than $40 \%(46 / 114)$ of psychiatric patients and in $22.5 \%$ (59/200) of healthy blood donors (10). Disparities in the results of these studies may reflect differences in the subject recruitment and sampling procedures.

The role of BDV in psychiatric disorders is controversial. However, other factors including gender, genetics and environment are involved in these diseases. Sex has been reported as a risk factor for psychosis (42).

We

also found that a higher percentage of schizophrenic patients were male, while most patients with bipolar disorder were female. However, this difference was not statistically significant and may be due to the difference in the number of female and male patients in each group. The role of genetics in development of bipolar disorder and schizophrenia has been well-established (43). There are some genetic loci which are believed to be associated with both diseases (44). Accordingly, we found that $51.2 \%$ of patients had a family history of mental illness. This findings was more evident in schizophrenic patients $(56.6 \%, 30 / 53)$ compared with patients with bipolar disorder $(47.1 \%, 33 / 70)$. 
In a cohort study performed in Denmark, it was demonstrated that first degree family history of mental illness is a risk factor for schizophrenia and bipolar disorder (45).

The subjects were also asked to report any previous contact with animals. Interestingly, cognitive disorders were significantly more prevalent in those having contact with horses and cats. BDV was first identified in horses and then in sheep, cattle, birds, rats, shrews, cats, and dogs (46-48). While this may suggest a possible role for BDV transmission from animals to human, we found no evidence of BDV genome sequences in any of the patients in contact with animals. This could be due to limitations of the RT-PCR in detection of possible BDV infections; however, we consider it unlikely. Meanwhile, it is well known that cats might become infected with $T$. gondii (49). Furthermore, psychiatric patients have high frequency of Toxoplasma antibodies and develop psychotic-like symptoms (5). Therefore, the more frequent contact with cats among psychiatric patients in this study may also be related to $T$. gondii infection, which requires further screening.

Education level is regarded as a critical factor for occupation and welfare in developing countries (50). Schizophrenic and bipolar disorder patients were found to be less educated compared to healthy blood donors. Therefore, unemployment and occupations with lower incomes were more common among psychiatric patients. A cohort study has reported that unemployment and low income are associated with psychiatric disorders in young people (51). Moreover, major depression is more frequent among

\section{REFERENCES}

1. Fears SC, Reus VI. Rosenberg's Molecular and Genetic Basis of Neurological and Psychiatric Disease. 2015; 1275-91.

2. Berrettini WH. Are schizophrenic and bipolar disorders related? A review of family and molecular studies. Vol. 48, Biological Psychiatry. 2000; 48(6): 5318. https://doi.org/10.1016/S0006-3223(00)00883-0.

3. Smoller JW, Finn CT. Family, twin, and adoption studies of bipolar disorder. Am J Med Genet [Internet]. 2003; $123 \mathrm{C}(1)$ : 48-58. https://doi.org/10.1002/ajmg.c.20013.

4. Mortensen PB, Pedersen CB, Westergaard T, Wohlfahrt J, Ewald H, Mors O, et al. Effects of Family History and Place and Season of Birth on the Risk of Schizophrenia. N Engl J Med. 1999; 340(8): 603-8. https://doi.org/10.1056/NEJM199902253400803. educationally unqualified and unemployed individuals with lower incomes (52). We found that psychiatric disorders are frequent (85.7\%) among female teachers. In Iran, teachers face two general and professional problems; relatively low salary and occupational stress. Lack of psychological counseling for teachers might be another contributing factor to the high prevalence of psychiatric disorders among teachers in Iran. However, the sample size for this group of individuals was small.

\section{CONCLUSION}

We found no evidence of BDV RNA among Iranian schizophrenic, bipolar and healthy blood donors. Contact with farm animals or cats as well as positive family history of mental illnesses could indicate a previous BDV infection. Therefore, animals in this region should be also screened for BDV infections. The present study also revealed that factors such as education level and occupation are associated with development of psychiatric disorders. Overall, absence of BDV genome could be a proof for absence of current infection. However, it is necessary to investigate previous viral infections using serological methods.

\section{ACKNOWLEDGMENTS}

This research was supported by the Golestan University of Medical Sciences (grant no: 35/266010), Gorgan, Iran.

\section{CONFLICTS OF INTEREST}

There is no conflict of interest to declare.

5. Yolken RH, Dickerson FB, Fuller Torrey E. Toxoplasma and schizophrenia. Parasite Immunol. 2009; 31(11): 706-15. doi: 10.1111/j.1365-3024.2009.01131.x.

6. Uher R. Gene-environment interactions in severe mental illness. Front Psychiatry. 2014; 5: 48. doi: 10.3389/fpsyt.2014.00048.

7. Cetinkaya Z, Yazar S, Gecici O, Namli MN. AntiToxoplasma gondii antibodies in patients with schizophrenia--preliminary findings in a Turkish sample. Schizophr Bull. 2007; 33(3): 789-91. https://doi.org/10.1093/schbul/sbm021.

8. Del Grande C, Galli L, Schiavi E, Dell'Osso L, Bruschi F. Is Toxoplasma gondii a Trigger of Bipolar Disorder? Pathogens. 2017; 6(1): 3. https://doi.org/10.3390/pathogens6010003. 
9. Yolken RH, Torrey EF. Viruses, schizophrenia, and bipolar disorder. Vol. 8, Clinical Microbiology Reviews. 1995; 8(1): 131-45.

10. Mazaheri-Tehrani E, Maghsoudi N, Shams J, Soori $\mathrm{H}$, Atashi $\mathrm{H}$, Motamedi $\mathrm{F}$, et al. Borna disease virus $(B D V)$ infection in psychiatric patients and healthy controls in Iran. Virol J. 2014; 11: 161. https://doi.org/10.1186/1743-422X-11-161.

11. Bode L, Reckwald P, Severus WE, Stoyloff R, Ferszt $\mathrm{R}$, Dietrich $\mathrm{DE}$, et al. Borna disease virus-specific circulating immune complexes, antigenemia, and free antibodies - The key marker triplet determining infection and prevailing in severe mood disorders. Mol Psychiatry. 2001; $6(4)$ : 481-91. https://doi.org/10.1038/sj.mp.4000909.

12. Li Q, Wang Z, Zhu D, Xu M, Chen X, Peng D, et al. Detection and analysis of Borna disease virus in Chinese patients with neurological disorders. Eur J Neurol. 2009; 16(3): 399-403. https://doi.org/10.1111/j.14681331.2008.02516.x.

13. Yamaguchi $K$, Sawada $T$, Naraki $T$, Igata-Yi R, Shiraki H, Horii Y, et al. Detection of borna disease virus-reactive antibodies from patients with psychiatric disorders and from horses by electrochemiluminescence immunoassay. Clin Diagn Lab Immunol. 1999; 6(5): 696-700.

14. Shatizadeh-Malekshahi S, Ahmadkhaniha HR, Kiani SJ, Nejati A, Janani L, Yavarian J. No molecular evidence of Borna disease virus among schizophrenia and bipolar disorder patients in Iran. Iran J Microbiol. 2017; 9(2): 112-118.

15. Brnic D, Stevanovic V, Cochet M, Agier C, Richardson J, Montero-Menei CN, et al. Borna disease virus infects human neural progenitor cells and impairs neurogenesis. J Virol. 2012; 86(5): 2512-22. https://doi.org/10.1128/JVI.05663-11.

16. Sauder C, Staeheli P. Rat model of Borna Disease Virus Transmission: Epidemiological Implications. J $\begin{array}{llll}\text { Virol. } & \text { 2003; } & 77(23): & 12886-90 .\end{array}$ https://doi.org/10.1128/JVI.77.23.12886-12890.2003.

17. Herzog S, Rott R. Replication of Borna disease virus in cell cultures. Med Microbiol Immunol. 1980; 168(3): 153-8. https://doi.org/10.1007/BF02122849.

18. Nakamura Y, Takahashi H, Shoya Y, Nakaya T, Watanabe $\mathrm{M}$, Tomonaga $\mathrm{K}$, et al. Isolation of Borna disease virus from human brain tissue. J Virol. 2000; 74: 4601-11. https://doi.org/10.1128/JVI.74.10.46014611.2000

19. Zheng YM, Schäfer MK, Weihe E, Sheng H, Corisdeo S, Fu ZF, et al. Severity of neurological signs and degree of inflammatory lesions in the brains of rats with Borna disease correlate with the induction of nitric oxide synthase. J Virol. 1993; 67(10): 5786-91.

20. Stitz L, Soeder D, Deschl U, Frese K, Rott R. Inhibition of immune-mediated meningoencephalitis in persistently Borna disease virus-infected rats by cyclosporine A. J Immunol. 1989; 143(12): 4250-6.

21. Richt JA, Pfeuffer I, Christ M, Frese K, Bechter K, Herzog S. Borna Disease Virus Infection in Animals and Humans. Emerg Infect Dis. 1997; 3(3): 343-52. https://doi.org/10.3201/eid0303.970311.
22. Chen CH, Chiu YL, Shaw CK, Tsai MT, Hwang AL, Hsiao KJ. Detection of Borna disease virus RNA from peripheral blood cells in schizophrenic patients and mental health workers. Mol Psychiatry. 1999; 4(6): 56671. https://doi.org/10.1038/sj.mp.4000568.

23. Waltrip RW, Buchanan RW, Carpenter WT, Kirkpatrick B, Summerfelt A, Breier A, et al. Borna disease virus antibodies and the deficit syndrome of schizophrenia. Schizophr Res. 1997; 23(3): 253-7. https://doi.org/10.1016/S0920-9964(96)00114-4.

24. Amsterdam JD, Winokur A, Dyson W, Herzog S, Gonzalez F, Rott R, et al. Borna Disease Virus: A Possible Etiologic Factor in Human Affective Disorders? Arch Gen Psychiatry. 1985; 42(11): 1093-6. https://doi.org/10.1001/archpsyc.1985.01790340077011.

25. Bode L, Ferszt R, Czech G. Borna disease virus infection and affective disorders in man. Arch Virol Suppl. 1993; 7: 159-67. https://doi.org/10.1007/978-37091-9300-6_13.

26. Zhang L, Xu M-M, Zeng L, Liu S, Liu X, Wang X, et al. Evidence for Borna disease virus infection in neuropsychiatric patients in three western China provinces. Eur J Clin Microbiol Infect Dis. 2014; 33(4): 621-7. https://doi.org/10.1007/s10096-013-1996-4.

27. Seyedi SM, Roodbari F, Mohseni M, Hosseini SH, Alaei OR. Molecular Detection of Borna Disease Virus in Patients with Schizophrenia in Mazandaran Province. J Maz Univ Med Sci. 2015; 24(122): 189-99.

28. Xu P, Xie P, Zou D, ZUO L. Detection of the Borna disease virus $P 24$ gene fragment in peripheral blood of patients with psychiatric disorders in China. Chinese $\mathbf{J}$ Zoonoses. 2004; 20: 471-3.

29. De la Torre JC, Gonzalez-Dunia D, Cubitt B, Mallory M, Mueller-Lantzsch N, Grässer FA, et al. Detection of Borna disease virus antigen and RNA in human autopsy brain samples from neuropsychiatric patients. Virology. 1996; 223(2): 272-82. https://doi.org/10.1006/viro.1996.0479.

30. Bode L. Human infections with Borna disease virus and potential pathogenic implications. Curr Top Microbiol Immunol. 1995; 190: 103-30. https://doi.org/10.1007/978-3-642-78618-1_7.

31. Nakaya T, Takahashi H, Nakamura Y, Asahi S, Tobiume M, Kuratsune H, et al. Demonstration of Borna disease virus RNA in peripheral blood mononuclear cells derived from Japanese patients with chronic fatigue syndrome. FEBS Lett. 1996; 378(2):145-9. https://doi.org/10.1016/0014-5793(95)01439-X.

32. Lipkin WI, Hornig M, Briese T. Borna disease virus and neuropsychiatric disease - A reappraisal. Trends $\begin{array}{llll}\text { Microbiol. } & \text { 2001; } & \text { 9(7): } & \text { 295-8. }\end{array}$ https://doi.org/10.1016/S0966-842X(01)02071-6.

33. Lipkin WI, Briese T, Hornig M. Borna disease virus - Fact and fantasy. Virus Res. 2011; 162(1-2): 162-72. https://doi.org/10.1016/j.virusres.2011.09.036.

34. Waltrip RW, Buchanan RW, Summerfelt A, Breier A, Carpenter WT, Bryant NL, et al. Borna disease virus and schizophrenia. Psychiatry Res. 1995; 56(1): 33-44. https://doi.org/10.1016/0165-1781(94)02600-N. 
35. Mohammadi Manesh M, Mohebbi A, Yasaghi M, Najafi Memar Z, Javid N, Taziki SA, et al. Low Prevalence of Borna Disease Virus RNA in Patients with Bipolar Major Depression and Schizophrenia in North of Iran. Iran J Virol 2017, 11(2): 8-13.

36. Kishi M, Nakaya T, Nakamura Y, Kakinuma M, Takahashi TA, Sekiguchi S, et al. Prevalence of Borna disease virus RNA in peripheral blood mononuclear cells from blood donors. Med Microbiol Immunol. 1995; 184(3): 135-8. https://doi.org/10.1007/BF00224350.

37. Evengard B, Briese T, Lindh G, Lee S, Lipkin WI. Absence of evidence of Borna disease virus infection in Swedish patients with Chronic Fatigue Syndrome. J Neurovirol [Internet]. 1999; 5(5): 495-9. https://doi.org/10.3109/13550289909045378.

38. Hornig $\mathrm{M}$, Briese $\mathrm{T}$, Licinio J, Khabbaz RF, Altshuler LL, Potkin SG, et al. Absence of evidence for bornavirus infection in schizophrenia, bipolar disorder and major depressive disorder. Mol Psychiatry. 2012; 17(5): 486-93. https://doi.org/10.1038/mp.2011.179.

39. Kim YK, Kim SH, Choi S-. H, Ko Y-. H, Kim L, Lee MS, et al. Failure to demonstrate Borna disease virus genome in peripheral blood mononuclear cells from psychiatric patients in Korea. J Neurovirol. 1999; 5(2): 196-9. https://doi.org/10.3109/13550289909022002.

40. Hagiwara K, Momiyama N, Taniyama H, Nakaya T, Tsunoda N, Ishihara C, et al. Demonstration of Borna disease virus $(B D V)$ in specific regions of the brain from horses positive for serum antibodies to BDV but negative for BDV RNA in the blood and internal organs. Med Microbiol Immunol. 1997; 186(1): 19-24. https://doi.org/10.1007/s004300050041.

41. Liu X, Bode L, Zhang L, Wang X, Liu S, Zhang L, et al. Health care professionals at risk of infection with Borna disease virus - Evidence from a large hospital in China (Chongqing). Virol J. 2015; 12(1): 39. https://doi.org/10.1186/s12985-015-0239-y.

42. Ochoa S, Usall J, Cobo J, Labad X, Kulkarni J. Gender differences in schizophrenia and first-episode psychosis: a comprehensive literature review. Schizophr Res Treatment. 2012; 2012: 916198. doi: $10.1155 / 2012 / 916198$
43. Cardno AG, Owen MJ. Genetic relationships between schizophrenia, bipolar disorder, and schizoaffective disorder. Schizophr Bull. 2014; 40(3): 504-15. https://doi.org/10.1093/schbul/sbu016.

44. Craddock N, O'Donovan MC, Owen MJ. The genetics of schizophrenia and bipolar disorder: dissecting psychosis. J Med Genet. 2005; 42(3): 193-204. https://doi.org/10.1136/jmg.2005.030718.

45. Laursen TM, Labouriau R, Licht RW, Bertelsen A, Munk-Olsen T, Mortensen PB. Family history of psychiatric illness as a risk factor for schizoaffective disorder: A Danish register-based cohort study. Arch Gen $\begin{array}{llll}\text { Psychiatry. } & \text { 2005; } & \text { 62(8): } & \text { 841-8. }\end{array}$ https://doi.org/10.1001/archpsyc.62.8.841.

46. Wensman JJ, Jäderlund KH, Holst BS, Berg M. Borna disease virus infection in cats. Veterinary Journal. 2014; 201(2):

142-9.

https://doi.org/10.1016/j.tvj1.2013.12.012.

47. Wensman J. Borna disease virus and its hosts. 2011; $1652-6880$.

48. Hilbe M, Herrsche R, Kolodziejek J, Nowotny N, Zlinszky K, Ehrensperger F. Shrews as reservoir hosts of borna disease virus. Emerg Infect Dis. 2006; 12(4): 6757. https://doi.org/10.3201/eid1204.051418.

49. Flegr J. Predictors of Toxoplasma gondii infection in Czech and Slovak populations: The possible role of catrelated injuries and risky sexual behavior in the parasite transmission. Epidemiol Infect. 2017; 145(7): 1351-62. https://doi.org/10.1017/S095026881700019X.

50. Gregorio J De, Lee J-W. Education and Income Inequality: New Evidence From Cross-Country Data. Rev Income Wealth. 2002; 48(3): 395-416. https://doi.org/10.1111/1475-4991.00060.

51. Gibb SJ, Fergusson DM, Horwood LJ. Burden of psychiatric disorder in young adulthood and life outcomes at age 30. Br J Psychiatry. 2010; 197(2): 1227. https://doi.org/10.1192/bjp.bp.109.076570.

52. Fergusson DM, Boden JM, Horwood LJ. Recurrence of major depression in adolescence and early adulthood, and later mental health, educational and economic outcomes. Br J Psychiatry. 2007; 191(OCT.): 335-42. https://doi.org/10.1192/bjp.bp.107.036079. 